Egyptian Poultry Science Journal

http://www.epsj.journals.ekb.eg/

ISSN: 1110-5623 (Print) - 2090-0570 (Online)

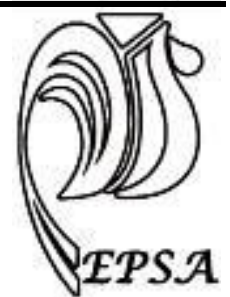

\title{
INFLUENCE OF BODY WEIGHT SELECTION FOR GIMMIZAH CHICKENS ON SOME GENETIC PARAMETERS RELATED TO HATCH
}

N. G. Boutrous; R. E. Rizk and O. M. Aly

Anim. Prod. Res. Inst., Agric. Res. Cent, Egypt

Corresponding Author: Nabile G. Boutrous, Email: Nabiiiiiiile.s.b@gmail.com

Received: 08/11/2020

Accepted: $28 / 11 / 2020$

\begin{abstract}
The present experiment was carried out for evaluation the influence of body weight selection at 12 -wk of age for Gimmizah chickens on hatching traits besides same genetic and phenotypic parameters related to it. The obtained results are summarized as follows: fertility percentage was numerically increased for first generation after selection of body weight compared with those for base population also, hatchability percentages were significantly decreased for the first generation compared with those for the base one population, while late and total embryonic mortalities were significantly increased for the first generation comparable to base one. Values of heritability for all studied parameters of fertility, hatchability and embryonic mortalities were low. Also, there are no obvious changes for heritability between base and $1^{\text {st }}$ generations with respect to all studied hatching traits. Moreover, most values of additive gene for fertility, hatchability and embryonic mortalities were low with relatively marked decrease for hatchability of total eggs among the base population and first generation. Highly positive significant phenotypic correlation was detected between fertility and hatchability of fertile eggs. While, all stages of embryonic mortalities represented highly negative significant phenotypic correlations with hatchability of fertile eggs. Moreover, hatchability of fertile eggs is genetically highly positive correlated with fertility. In conclusion fertility, hatchability and embryonic mortality could be considered in designing the program of improving body weight for Gimmizah chickens and this criteria should be involved in the selection index.
\end{abstract}

Key words: Gimmizah chickens - selection - hatchability - fertility - embryonic mortality 
INTRODUCTION
Selection for body weight is the most important trait of genetic improvement program because that body weight is easily measured and correlated with several other traits (Saleh et al., 2008, and Ramadan et al., 2014).

Fertility and hatchability can be maintained in populations under multiple trait selection through culling of paternal and maternal families with low performance. This culling only of families with low fertility and hatchability allows the breeder to use higher selection intensity to obtain greater genetic progress in primary traits such as egg production (Fairfull, 1990).

Hatchability is a typical fitness trait with low heritability, which suggests that optimization of breeder farm and hatchery management is the most promising route for improvement (Förster et al., 1992). However, low heritability does not exclude improvement by selection, it only takes a long time to see measurable results and estimates of heritability for hatch of fertile eggs in the literature ranges from 0.02 to 0.24 (Sharifi et al., 2010; Wolc et al., 2010). It has been suggested that the decrease in viability of the embryo may be caused by changes in the embryo or by changes in certain physical aspects of the eggs (Becker, 1960).Consequently, heritability value for mid-term embryonic mortality is important for improving hatchability(Gwaza et al., 2016.)

Genetic selection for traits such as growth rate and yield have been negatively associated with the expression of morphometric traits related to reproduction (Soller et al., 1965; Siegel and Dunnington, 1985). Specifically, male body weight is known to directly impact reproduction in broiler breeders (Wilson et al., 1979; Siegel and Dunnington, 1985).

The direct additive genetic component of any trait can be estimated from a single observation per birds, however, shared environmental effects can also give rise to phenotypic covariance between related individuals (Kruuk and Hadfield, 2007). In domestic fowl variation of the ratio of chromosome abnormalities was found among different breeds, families and individuals (Thorne and Sheldon., 1991). This study was performed to evaluate the influence of body weight selection at 12wk of age for Gimmizah chickens on some hatching traits besides estimating the genetic and phenotypic parameters of hatching out-put.

\section{MATERIALS AND METHODS}

The present study was conducted at ElSabahia Poultry Research Station, Alexandria, Agriculture Research Centre. Three hundred and fifty two Gimmizah chickens for both sexes were mated in family pens and each family composed of one sire and ten females and formed as base population. The pedigreed chicks produced from the base generation were wing-banded. Males and females at 12wk of age were selected according to individual selection. After 20 weeks of age, selected males and females were transferred into family pens. Three thousands, four hundreds and fifty hatching eggs obtained from Gimmizah chickens at 45-50 wks of age representing the base population and first generation (1850 and 1600 eggs, respectively) were used for evaluation the hatching traits. All collected eggs were individually pedigreed the pedigreed eggs were collected from sire families then weighed 
Gimmizah chickens - selection - hatchability - fertility - embryonic mortality

prior to the beginning of the incubation and incubated in Egyptian- made incubator at $99.5^{\circ} \mathrm{F}$ and $55 \% \mathrm{RH}$ during setting phase and $98.6^{\circ} \mathrm{F}$ with $65 \% \mathrm{RH}$ during hatching phase. Eggs for each generation were randomly distributed in trays as replicates in the incubator.

On the $18^{\text {th }}$ day of incubation, eggs for each generation were candled and those with evidence of living embryos were transferred to the hatcher with the same experiential design: The infertile eggs were macroscopically evaluated to demine apparent infertility by necked eyes. Eggs that failed to hatch at the end of incubation and having full opportunity for hatch were broken out and then examined with necked eye to estimate embryonic mortality and assigned according to their times of death in days as possible. Embryonic mortality percentages expressed as a percentage of fertile eggs set were recorded and classified into different intervals as early (1-7), middle (8-14) and late (15 -21) days of incubation. Macroscopic fertility was calculated as a percentage of fertile eggs relative to total eggs set. Hatchability was calculated as the percentages of sound chicks that hatched from either total or fertile eggs.

\section{Statistical analyses:}

The first step, the mixed model was defined to analyze the data, get the Restricted Maximum Likelihood (REML) estimates of the variance and covariance components. These estimates were used in the prediction equations of the additive values of all animals as directed by Sorensen and Kennedy (1984). The following animal model shown in matrix notation was used to estimate genetic parameters for the fertility, hatchability of total eggs, hatchability of fertile eggs, early embryonic mortality, middle embryonic mortality, late embryonic mortality, and total embryonic mortality traits, as well as means of all traits. REML co-variance components were estimated by series of multivariate animal models (allowing to estimate correlations among traits) using WOMBAT software (Meyer, 2006).

The model can be represented in matrix terms by

$\mathrm{Y}=\mathrm{Xb}+\mathrm{Za}+\mathrm{e}$

Where, $\mathrm{y}$ is the vector of observations; $\mathrm{X}$ is the incidence matrix of fixed effects; $b$ is the vector of fixed effects (generation); $\mathrm{Z}$ is the incidence matrix of random effects; $a$ is the vector of random effects; $\mathrm{e}$ is the vector of residuals.

Genetic, phenotypic, and environmental correlations were estimated using biraviate analyses with the same fixed effects in univariate models (Yavarifard et al., 2015).

Heritability was computed according to Boldman et al. (1995) as:

$$
h^{2}=\frac{\sigma_{a}^{2}}{\sigma_{a}^{2}+\sigma_{e}^{2}}
$$

Where $\sigma_{a}^{2}$ and $\sigma_{e}^{2}$ are variances due to effects of direct additive genetic and random error, respectively.

Numbers of preliminary analyses were done using SAS (2004) for checking listing all data. The following model was used:

$$
Y_{i k}=\mu_{+} s_{i}+e_{i k}
$$

Where

$\mathrm{Y}_{\mathrm{ik}}=$ the phenotypic measurements for the individual from $\mathrm{K}^{\text {th }}$ sire.

$\mu \quad=$ general mean for the measurement.

$\mathrm{s}_{\mathrm{i}}=$ effect common to all individual from $i^{\text {th }}$ sire.

$\mathrm{e}_{\mathrm{ik}}=$ the experimental error.

Differences between each means were done according to Duncan (1955). 


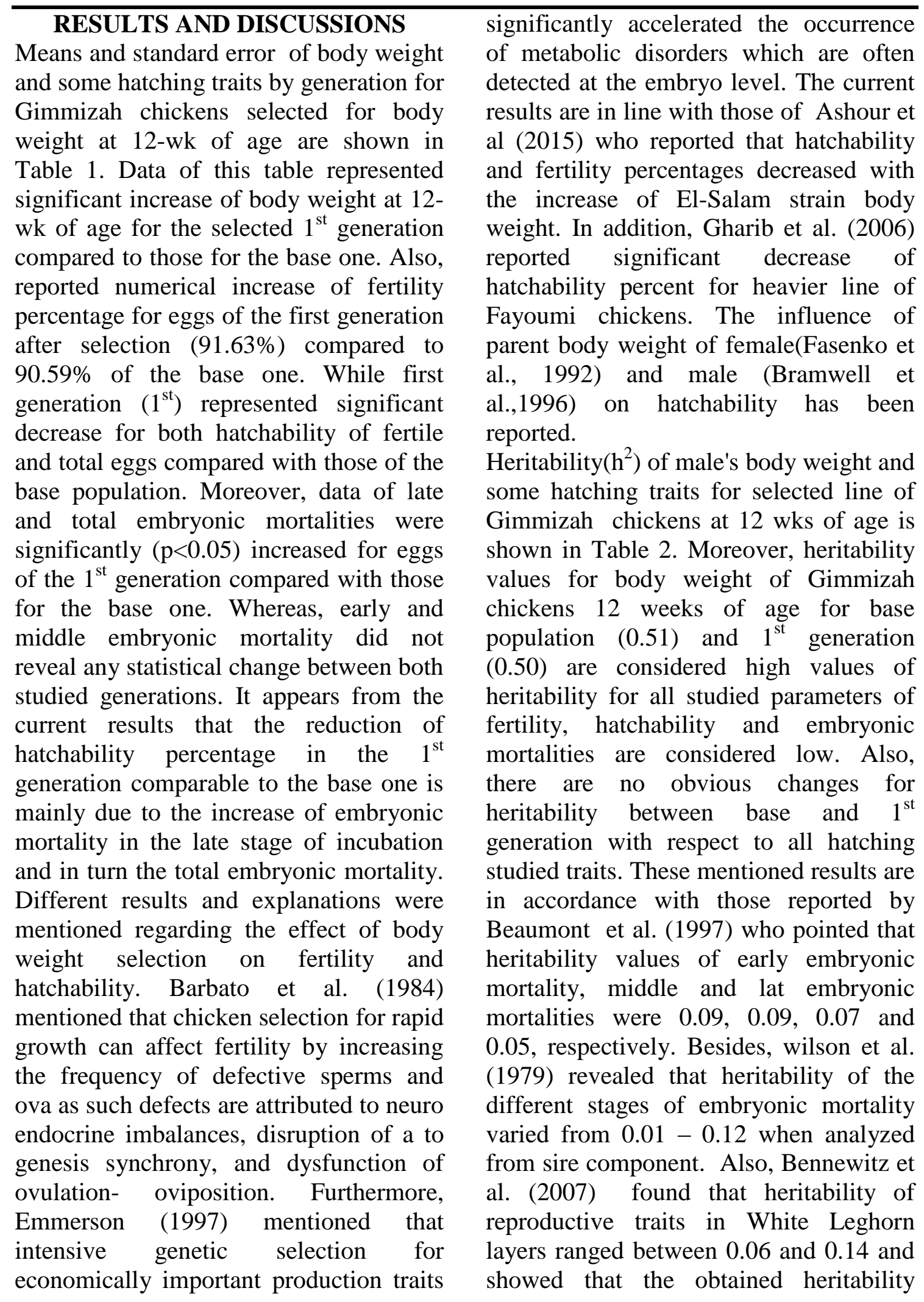


estimates were higher compared with the expected values obtained from linear model. Moreover, Wolc et al. (2010) found that the heritability of fertility and hatchability of fertile eggs was low, ranging between 0.005 and 0.105 for the male component. Furthermore, Zhang (2016) estimated heritability for fertility could be biased on the founding effect of early embryonic mortality and fertility. However low heritability does not exclude improvement by selection but it only takes a long time to get measurable results (Wolc et al., 2010).

Data of Table 3. demonstrate additive genetic $\left(\mathrm{V}_{\mathrm{A}}\right)$ and standard error (SE) of males body weight and some hatching traits for Gimmizah chickens selected for body weight at 12 wks of age. Most values of additive genetic for fertility, hatchability and embryonic mortalities are considered low with relatively marked decrease of hatchability for total eggs among the experimental studied generations. Moreover, data of both generations did not represent any noticeable change with respect to fertility, hatchability of fertile eggs and embryonic mortality except that for total embryonic mortality as represented 0.59 and 0.65 for both studied generations. This increase of additive genetic for total embryonic mortality in the $1^{\text {st }}$ generation after selection compared the base one could help for improving this trait through indirect selection with other related traits. The importance of genetic factor on embryonic mortality and subsequently on hatching out-put were detected in different publications. Lariviere et al. (2009) showed the genetic influence on embryonic mortality for traditional chicken breed and they added that there are variation in genetic parameters estimates from sire variance components due to breed. Also, Takashi et al. (2011) reported that genetic factors area predominate during embryonic death in native chicken breed. Moreover, Gwaza et al. (2015) mentioned significant $(\mathrm{P}<0.05)$ differences that existed between the sires within the ecotype indicated that there was a genetic background on embryonic mortality that was affected by the variation in the additive genetic differences between the sires used.

Phenotypic and genetic correlations of fertility, hatchability of fertile eggs and embryonic mortality for Gimmizah chickens are presented in Table 4. Data of this table demonstrated highly positive significant phenotypic correlation $(p<001)$ between fertility with body weight for males and hatchability of fertile eggs. While, all stages of embryonic mortality represented highly negative $\quad(p<001)$ correlations with hatchability of fertile eggs. Moreover, hatchability of fertile eggs is highly positive genetic correlated with fertility (0.99). Whereas, hatchability of fertile eggs is highly negative genetic correlated with all stages of embryonic mortality. Also, highly significant negative genetic correlation was observed between early and late embryonic mortalities. The highly significant positive phenotypic correlation between fertility and hatchability of fertile eggs in this study is in harmony with those of earlier works by Islam et al. (2002) and Adedeji et al. (2015). Moreover, the currents of negative and significant phenotypic correlations between hatchability of fertile eggs and all stages of embryonic mortality including total embryonic mortality were confirmed by Islam et al. (2002) Also, the same authors come to the same our results regarding the nonsignificant and positive phenotypic 


\section{N. G. Boutrous. Et al.}

correlation between fertility and total embryonic mortality. However, Adedeji et al. (2015) reported that there were positive phenotypic correlations between fertility and all stages of embryonic mortalities but with significant estimates. The highly genetic correlation between fertility and hatchability of fertile eggs added credence to the previous findings of Beaumont et al. (1997) who found that genetic correlation estimates between both traits are high from sire and dam components. Also, Sapp et al. (2004), Boutrous et al. (2016) and Zhang (2016) estimated genetic correlations between fertility and hatchability of the fertile eggs and they found moderate to high values and ranged from 0.32 to 0.97 . Besides, Savegnago et al. (2011) documented the highly positive correlation between the both estimated traits indicated that any of these traits can be improved genetically by selecting for one of them, and they added that selection for fertility and hatchability is based on a hypothesis of selection against segregation of deleterious recessive genes probably at low frequencies, with a presumption that the heritability is low. Our estimates of negative correlation between hatchability of fertile eggs and susceptibility to the intervals of embryonic death are generally favourable. So, selecting for increasing hatchability should result in decreased embryonic mortalities and reciprocally, selection for decreasing embryonic mortality should allow an indirect increase in hatchability of fertile eggs. It is clear from this study that fertility and embryonic mortality through incubation intervals are sub-traits of hatchability and should be maintained at optimum levels in designing the program of improving body weight of Gimmizah chickens.

\section{CONCLUSION}

Selection for body weight at 12 -wk of age in Gimmizah chickens could affect the fertility and embryonic mortality and consequently the hatchability of fertility eggs suggesting that these traits should be included as selection criteria in genetic breeding 

Table (1): body weight for males at 12-wk of age and some hatching traits for selected Gimmizah chickens

\begin{tabular}{|l|c|c|}
\hline Traits & Base population & $\mathbf{1}^{\text {st }} \overline{\text { generation }}^{\overline{\boldsymbol{X}} \pm \text { S.E }}$ \\
\hline Body weight for males (g) & $\overline{\boldsymbol{X}} \pm \mathbf{S . E}$ & $1458.78 \pm 70.04^{\mathrm{a}}$ \\
Fertility \% & $1345.78 \pm 12.04^{\mathrm{b}}$ & $91.63 \pm 1.03$ \\
Hatchability of total eggs \% & $90.59 \pm 0.47$ & $78.70 \pm 1.02^{\mathrm{b}}$ \\
Hatchability of fertile eggs \% & $81.80 \pm 0.62^{\mathrm{a}}$ & $86.74 \pm 1.08^{\mathrm{b}}$ \\
Early embryonic mortality(1-7 days) \% & $90.30 \pm 0.50^{\mathrm{a}}$ & $3.26 \pm 0.83$ \\
Middle embryonic mortality(8-14 days)\% & $2.13 \pm 0.25$ & $1.74 \pm 0.61$ \\
Late embryonic mortality(15-21 days)\% & $2.88 \pm 0.28$ & $8.26 \pm 0.78^{\mathrm{a}}$ \\
Total embryonic mortality \% & $4.73 \pm 0.36^{\mathrm{b}}$ & $12.03 \pm 1.04^{\mathrm{a}}$ \\
\hline
\end{tabular}

$a$ and $b$ Means within each row with different superscripts are significantly different $(p<0.05)$

\& Table (2): Heritability $\left(\mathrm{h}^{2}\right)$ and standard error (SE) for male's body weight and some hatching traits by generations for the selected line of Gimmizah chicken .

\begin{tabular}{|l|c|c|}
\hline Traits & $\begin{array}{c}\text { Base population } \\
\mathbf{h}^{\mathbf{2}} \pm \mathbf{S . E}\end{array}$ & $\begin{array}{c}\mathbf{1}^{\text {st }} \text { generation } \\
\mathbf{h}^{\mathbf{2}} \pm \text { S.E }\end{array}$ \\
\hline Body weight for males at12-wk of age & $0.510 \pm 0.01$ & $0.500 \pm 0.010$ \\
Fertility & $0.060 \pm 0.050$ & $0.060 \pm 0.004$ \\
Hatchability of total eggs & $0.023 \pm 0.050$ & $0.022 \pm 0.100$ \\
Hatchability of fertile eggs & $0.060 \pm 0.006$ & $0.060 \pm 0.006$ \\
Early embryonic mortality(1-7 days) & $0.060 \pm 0.006$ & $0.060 \pm 0.004$ \\
Middle embryonic mortality(8-14 days) & $0.060 \pm 0.006$ & $0.060 \pm 0.004$ \\
Late embryonic mortality(15-21 days) & $0.060 \pm 0.006$ & $0.060 \pm 0.004$ \\
Total embryonic mortality & $0.060 \pm 0.040$ & $0.052 \pm 0.180$ \\
\hline
\end{tabular}


Table(3):Additive genetic $\left(\mathrm{V}_{\mathrm{A}}\right)$ and standard error (SE) of body weight for males and some hatching traits for the selected Gimmizah chickens

\begin{tabular}{|c|c|c|}
\hline Traits & $\begin{array}{c}\text { Base population } \\
V_{A} \pm \text { S.E }\end{array}$ & $\begin{array}{c}\text { 1st generation } \\
\mathrm{V}_{\mathrm{A}} \pm \mathrm{S} . \mathrm{E}\end{array}$ \\
\hline Body weight for males & $1.08 \pm 0.74$ & $1.08 \pm 0.15$ \\
\hline Fertility & $0.60 \pm 0.008$ & $0.61 \pm 0.01$ \\
\hline Hatchability of total eggs & $0.34 \pm 0.860$ & $0.39 \pm 0.26$ \\
\hline Hatchability of fertile eggs & $0.60 \pm 0.008$ & $0.60 \pm 0.01$ \\
\hline Early embryonic mortality(1-7 days) & $0.60 \pm 0.001$ & $0.61 \pm 0.02$ \\
\hline Middle embryonic mortality(8-14 days) & $0.60 \pm 0.001$ & $0.61 \pm 0.01$ \\
\hline Late embryonic mortality(15-21 days) & $0.60 \pm 0.001$ & $0.61 \pm 0.01$ \\
\hline Total embryonic mortality & $0.59 \pm 0.035$ & $0.65 \pm 0.02$ \\
\hline
\end{tabular}

Table (4):Phenotypic (above diagonal) and genetic (below diagonal), correlations of body weight and some hatching traits for Gimmizah chickens

\begin{tabular}{|c|c|c|c|c|c|c|c|}
\hline Traits & $\begin{array}{c}\text { Body } \\
\text { weight for } \\
\text { males }\end{array}$ & $\begin{array}{c}\text { Hatchability } \\
\text { of fertile } \\
\text { eggs }\end{array}$ & Fertility & $\begin{array}{c}\text { Early } \\
\text { embryonic } \\
\text { mortality } \\
\text { (1-7 days) }\end{array}$ & $\begin{array}{c}\text { Middle } \\
\text { embryonic } \\
\text { mortality } \\
\text { (8-14 days) }\end{array}$ & $\begin{array}{c}\text { Late } \\
\text { embryonic } \\
\text { mortality } \\
(\mathbf{1 5 - 2 1} \text { days })\end{array}$ & $\begin{array}{c}\text { Total } \\
\text { embryonic } \\
\text { mortality } \\
\text { for total } \\
\text { eggs }\end{array}$ \\
\hline Body weight for males & & -0.33 & $0.94^{\text {**** }}$ & 0.08 & 0.11 & 0.06 & 0.25 \\
\hline Hatchability of fertile eggs & $0.10+0.01$ & & $0.67^{* * * *}$ & $-0.46 * * *$ & $-0.50 * * *$ & $-0.69 * * *$ & $-0.67 * * *$ \\
\hline Fertility & $0.10+0.01$ & $0.99 \pm 0.003$ & & 0.000 & 0.002 & -0.09 & 0.09 \\
\hline Early embryonic mortality & & $-0.50 \pm 0.15$ & & & -0.03 & -0.04 & $0.46^{* * *}$ \\
\hline Middle embryonic mortality & & $-0.30 \pm 0.14$ & $0.36 \pm 0.04$ & $-0.17 \pm 0.04$ & & -0.04 & $0.50 * * *$ \\
\hline Late embryonic mortality & & $0.98 \pm 0.01$ & & $-0.70 \pm 0.12$ & $0.16 \pm 0.02$ & & $0.69 * * *$ \\
\hline Total embryonic mortality & $0.10+0.01$ & $-0.84 \pm 0.11$ & $0.88 \pm 0.08$ & $0.11 \pm 0.01$ & & & \\
\hline
\end{tabular}

***: Significant differences at $\mathrm{P}<0.001$ 

Gimmizah chickens - selection - hatchability - fertility - embryonic mortality

\section{REFERENCES}

Adedeji, T. A.; Amao, S. R.; Popoola, A. D.; and Ogundipe, R. I. 2015. Fertility, hatchability and eggs quality traits of nigerian locally adapted chickens in the derived savanna environment of Nigeria. Journal of Biology, Agriculture and Healthcare., 5: 36-42.

Ashour, A. F.; Badwi, Y. K.; and Ragaa. Abd EL-Karim, E. 2015. Effect of selection for body weight on egg production, egg quality, fertility and hatchability traits in El-Salam chicken strain in Egypt. Anim. And pout. prod., Mansoura Univ., 6: 781-796.

Barbato, G. F.; Siegel, P. B.; Cherry, J. A.; and Nir, I. 1984. Selection for body weight at eight weeks of age. Poult. Sci., 63: 11-18.

Beaumont, C.; Millet, N.; Le BihanDuval, E.; Kipi, A.; and Dupuy, V. 1997. Genetic parameters of survival to the different stages of embryonic death in laying hens. Poult. Sci., 76: 1193-1196.

Becker, W. A. 1960. The storage of hatching eggs and the posthatching body weights of chickens. Poult. Sci., 39: 588-590.

Bennewitz, J.; Morgades, O.; Preisinger, R.; Thaller, G.; and Kalm, E. 2007. Variance component and breeding value estimation for reproductive traits in laying hens using a bayesian threshold model. Poult. Sci., 86: 823-828.

Boldman, K. G.; Kriese, L. A.; Van Vleck, L. D.; Van Tassell, C. P.; and Kachman, S. D. 1995. A manual for use of MTDFREML. A set of programs to obtain estimates of variances and covariances. U.S. Department of Agriculture, Agricultural Research Service, USA.

Boutrous, N .G.; Aly, O. M.; and ELSheikh, A. M. H. 2016. Estimating some genetic parameters of embryonic mortality in gimmizah chicken breed.

Egypy. poult. Sci., 36: 1223-1231.

Bramwell, R. K.; McDaniels, C. D.; Wilson, J. L.; and Howarth, B. 1996. Age effect of male and female broiler breeders on sperm penetration of the perivitelline layer overlying the germinal disc. Poult. Sci., 75:755-762.

Duncan, D. B. 1955. Multiple ranges and multiple F test. Biometrics. 11: 1-42.

Emmerson, D. A. 1997. Commercial approaches to genetic selection for growth and feed conversion in domestic poultry. Poult. Sci., 76: 1121-1125.

Fairfull, R. W. 1990. Heterosis. Pages 913-933 in Poultry Breeding and Genetics. R. D. Crawford, ed. Elsevier Science, Amsterdam.

Fasenko, G. M.; Hardin, R. T.; and Robinson, F. E. 1992. Relationship of hen age and egg sequence position with feritility, hatchability, viability, and preincubation embryonic development in broiler breders. Poult. Sci., 71: 1374-1383.

Förster, A.; Kalm, E.; and Flock, D. K. 1992. Schlupffähigkeit aus züchterischer Sicht. Lohmann nformation (Sept./Okt.):13-16.

Gharib, H. B. A.; Atta, A. M. M.; ELMenawey, M. A.; and Stino, F. K. R. 2006. Effects of divergent selection for primary antibody titers against sheep red blood cells on some immunological and productive performance of chickens. Egypt. Poult. Sci., 26: 1549-1566.

Gwaza, D. S.; Dim, N. I.; and Momoh, O. M. 2015. Investigation of possible genetic background of embryonic mortality in two populations of Nigeria local chicken ecotypes. Asian Journal of Agriculture and Food Sciences., 3: 541-550. 
Gwaza, D. S.; Dim, N. I.; and Momoh, O. M. 2016. Evaluation of Sire and Dam for Genetic Improvement of Fertility, Embryonic Mortality and Hatchability in Nigerian Local Chickens Populations. Adv Genet Eng., 5: 1-6.

Islam, M. S.; Howlider, M. A. R.; Kabir, F.; Alam, J. 2002. Comparative assessment of fertility and hatchability of Barred Plymouth Rock, White Leghorn, Rhode Island Red and White Rock hen. Int. J. Poult. Sci., 1: 85-90.

Kruuk, L. E. B.; and Hadfield, J. D. 2007. How to separate genetic and environmental causes of similarity between relatives. J. Evol. Biol., 20: 1890-1903.

Lariviere, J. M; Michaux, C.; Farnir, F.; Detilleux, J.; Verleyen, V.; and Leroy, P. 2009. Reproductive performance of the ardennaise chicken breed under traditional and modern breeding management systems. Int. J. Poult. Sci., 8: 446-451.

Meyer, K. 2006. WOMBAT - A program for mixed model analyses byrestricted maximum likelihood. User notes. Animal Genetics and Breeding Unit, Armidale, 83 pp.

Ramadan, G. S.; Moghaieb, R. E.; ELGhamry, A. A.; El-Komy, E. M.; Nassar, F. S.; Abdou, A. M.; Ghaly, M. M.; Stino, F. K. R. 2014. Effect of selection for high live body weight on slaughter performance of broiler breeders. Egyptian Poult. Sci., 34: 289-304.

Saleh, K.; Younis, H. H.; Rizkalla, H. E.; and Ragaa, E. Abd El-Krim 2008. Direct and correlated response of selection for improving body weight in El-Salam chickens. Egypt. Poult. Sci., 28: 431-454.

Sapp, R. L.; Rekaya, R.; Misztal, I.; and Wing. T. 2004. Male and female fertility and hatchability in chickens: A longitudinal mixed model approach. Poult. Sci., 83: 1253-1259.

SAS. 2004. SAS/STAT users guide. SAS Institute INC, Cary, nc27513, USA.

Savegnago, R. P. ; Buzanskas, M. E. ; Nunes, B. N. ; Ramos, S. B. ; Nones, K.; and Munari, D. P. 2011. Heritabilities and genetic correlations for reproductive traits in an F2 reciprocal cross chicken population. Genetics and Molecular Research., 10: 1337-1344.

Sharifi, A. R.; Preisinger, R.; Vahidi, F.; Jawasreh, K.; and Simianer, $H$. 2010. Statistical and genetic analysis of reproductive traits in laying hens. Proceedings of the 9th World Congress on Genetics Applied to Livestock Production, Leipzig, Germany.

Siegel, P. B.; and Dunnington, E. A. 1985. Reproductive complications associated with selection for broiler growth. Br. Poult. Sci., 26: 59-72.

Soller, M.; Snapir, N.; and Schlinder, H. 1965. Heritability of semen quantity, concentration and motility in White Rock roosters, and their genetic correlations with rate of gain. Poult. Sci., 44: 1527-1529.

Sorensen, D. A.; Kennedy, B. W. 1984. Estimation of response to selection using least squares and mixed model methodology. Journal Anim. Sci., 85: 1097-1106.

Takashi, B.; Tatsuhiko, G.; Jun-Ichi, S.; and Masaoki, T. 2011. Embryonic and chick mortality of four native japanese chicken breeds. Journal of 
Gimmizah chickens - selection - hatchability - fertility - embryonic mortality

Animal and Verterinary advances., 10: 701-703.

Thorne, M. H.; and Sheldon, B. L. 1991. Cytological evidence of maternal meiotic errors in a line of chickens with a high incidence of triploidy. Cytogenet Cell Genet., 57: 206-210.

Wilson, H. R; Piesco, N. P; Miller, E. R; and Nesbeth, W. G. 1979. Prediction of potential of broiler breeder males. World's Poult. Sci., journal 35: 95-118.

Wolc, A.; White , I. M. S.; Hill, W. G.; and Olori, V. E. 2010. Inheritance of hatchability in broiler chickens and its relationship to egg quality traits. Poult. Sci., 89: 2334-2340.

Yavarifard, R.; Ghavi Hossein-Zadeh, N.; Shadparvar, A. A. 2015. Estimation of genetic parameters for reproductive traits in Mehraban sheep. Czech J. Anim. Sci., 60: 281-288.

Zhang, Yi.; 2016. Studies on chicken hatchability and its relation with egg yolk metabolites. Ph.D. Faculty of Agricultural Sciences, Georg-AugustUniversity Göttingen, Germany.

\section{تأثير الانتخاب لوزن الجسم لاجاج الجميزة على بعض العربى المقاييس الوراثية ذات العلاقة بالفقس}

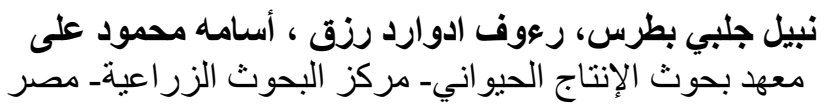

أجريت هذه التجربة لتقييم اثر انتخاب دجاج الجميزة لوزن الجسم عند عمر بال أسبوع على وزن الجسم وبعض

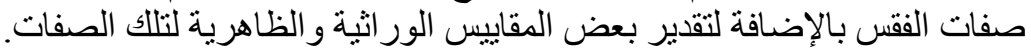





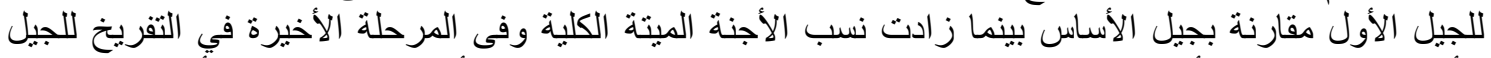

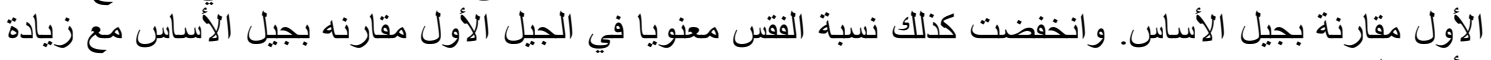

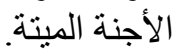
وسجلت قيم المكافئ الور اثي لكل من الخصوبة والفقس والأجنة الميتة انخفاضا فى جيل الأساس والجيل الأول

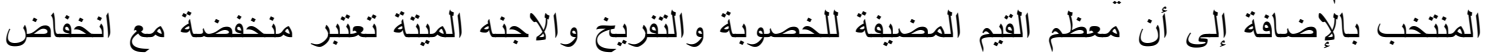

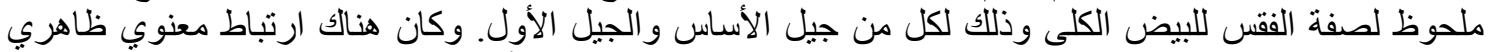

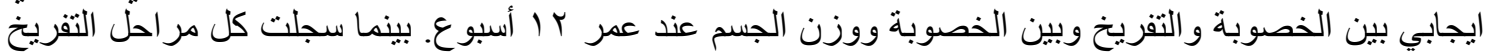
الجنيني ارتباط معنوي عالي ظاهري سالب مع الفقس للبيض الكلى الفي بالإضافة إلى ذلى اللك سجل الإرتباط الظاهري

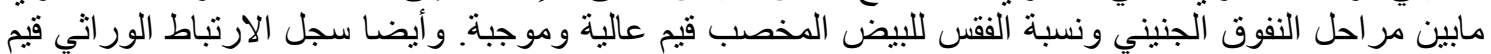

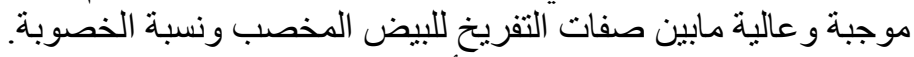

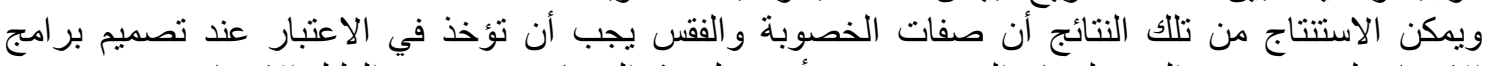
الاتنخاب لتحسين وزن الجسم لاجاج الجميزة ويجب أن النئ تدخل هذه الصفات في تصميم الدليل الانتخابي. 